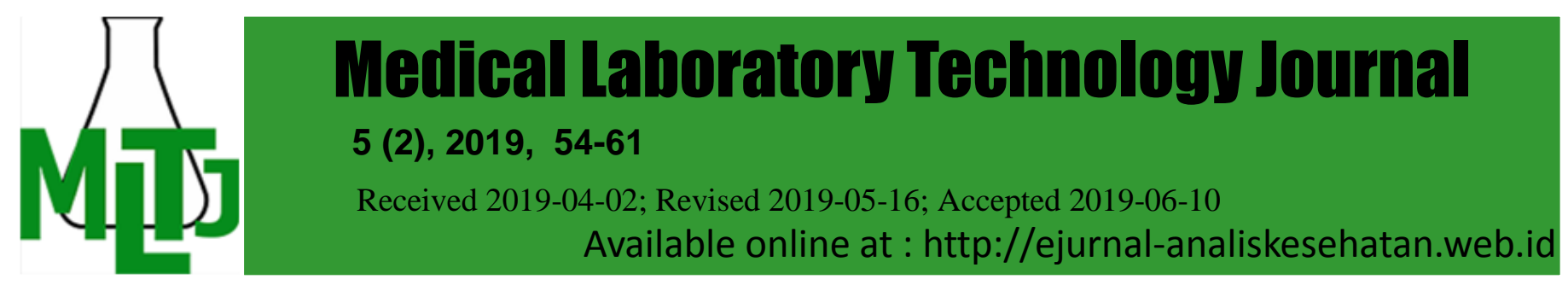

\title{
The Comparison of Widal Slide Examination Results between Tubex TF on Febrile Observation Patients Over 3 Days
}

\author{
*Nosa Ika Cahyariza, Rofiatu Sholihah \\ Immunology Study, Postgraduate Faculty, Universitas Airlangga Campus B \\ Jl. Airlangga No.4 - 6, Airlangga, Gubeng, Surabaya, East Java 60115 \\ *Email : nosaika91@gmail.com \\ DOI: $10.31964 / \mathrm{mltj} . v \%$ vi\%i.212
}

\begin{abstract}
Typhoid fever is systematic bacterial disease usually occurs and has a high mortality rate each year, a disease transmitted from person to person due to contamination of feces, food, and water. The cause is bacterium Salmonella enterica serovar Typhi (S. Typhi) which is a natural host and reservoir for human. The limitations of the diagnostic test led to the increasing mortality rate due to typhoid fever. Besides ensuring infection in individuals, accurate serological tests are needed to ascertain the actual burden of the disease. Serological tests which are usually carried out in Puskesmas and hospital are Widal and Tubex Tf examinations. This study aims to determine whether there are differences in Widal and Tubex TF serological examinations in febrile patients over three days non-typhoid so patients can immediately find out whether they have typhoid fever or not. This study used a laboratory exploration method by examining 24 samples using Widal TYDAL and TUBEX $®$ TF IDL Biotech. As many as 24 samples were examined by widal with antisera $\mathrm{O}, \mathrm{H}, \mathrm{AH}$, and $\mathrm{BH}$. Twenty-four of the same samples analyzed by TUBEX® TF. Results comparison of diagnostic from both methods will be compared using Mc Nemar test with significance $=0.05$. Based on the examination which had done, it showed the difference in the results of Widal slide and Ig M Anti Salmonella (Tubex Tf) in patients with febrile observation over three days. So, it can conclude that Tubex Tf examinations were better that widal slide examination because Tubex Tf uses Salmonella typhi antiO9 antigen which can distinguish these organisms from $>99 \%$ other Salmonella bacteria serotypes so that Tubex Tf examination is more specific.
\end{abstract}

Keyword: fever; Widal slide; Tubex TF

\section{INTRODUCTION}

Fever or debris is a process in which average body temperature rises to a state of homeostasis. Fever is one of the clinical symptoms that usually appear in some infectious diseases. For example, is enteric fever caused by Salmonella sp (Plaza et al. 2016). In General, the body's rectal temperature range between $36^{\circ} \mathrm{C}$ to $37.8{ }^{\circ} \mathrm{C}$ (Solimani et al., 2015). The American College of Critical Care Medicine, the International Statistical Classification of Diseases, and The Infectious Diseases Society of America Society of infectious diseases of the United States that can be described as fever if body temperature reaching $38.3^{\circ} \mathrm{C}$ or higher, i.e., just above the upper limit of normal human temperature. (Walter et al., 2016). World Health Organization (WHO) estimates the number of fever cases in the entire world reaches $16-33$ million, with 
500-600 thousand deaths each year (Wardiyah, Setiawati, \& Romayati, 2016).

There are three main patterns of fever: continuous fever, intermittent fever, and remittance fever. Illness can be defined as a persistent fever if fluctuations of body temperature not more than $1^{\circ} \mathrm{C}\left(1,5^{\circ} \mathrm{F}\right)$ for 24 hours. Continuous fever is a symptom of the disease such as lobar pneumonia and Gram-negative, typhoid, meningitis, an acute bacterial infection of the urinary tract. Fever which characterized by gradual slow temperature rise and high altitude is a classic symptom of typhoid fever (Ogoina, 2011). Typhoid fever (enteric) is a significant health problem. World Health Organization reveals that around 21 million cases and more than 600,000 annual deaths from typhoid fever occur throughout the world. Developing countries have the highest burden due to rapid population growth, increased urbanization, water system, and limited healthy (Wasihun et al., 2015).

Typhoid fever is a systemic bacterial disease that is very common in the community. This disease is transmitted from person to person because it contaminated with feces, food, and water. The cause is Salmonella enterica serovar Typhi (S. Typhi), which is a natural host and reservoir for human. The human can be chronic carriers, and poor food handling practices can lead to the contamination and transmission of S. Typhi (Ramani, Park, Wierzba, Mogasale, \& Mogasale, 2018). The limitations of diagnostic tests cause the increasing mortality rate due to typhoid fever. Besides ensuring infection in individuals, accurate laboratory checks are needed to ensure the true burden of the disease (Zhou et al., 2017).

Some countries use serological tests to diagnose typhoid fever. Serological tests which usually conducted in Puskesmas and hospital are Widal and Tubex Tf examinations. Widal test is the most widely used method for diagnosing typhoid fever in many developing countries (Abutiheen, 2016). This test is easy and inexpensive, so it commonly used in developing countries. TUBEX® TF is a rapid in vitro test with method of inhibition magnetic binding immunoassay (IMBI) which can detect specific IgM to O9 Salmonella enterica Serovar Typhi antigen found in the serum of patients. Antibodies inhibit the reaction between antigen coated with magnetic particles and antibodies coated with colored latex particles (Ilham, Nugraha, \& Purwanta, 2017). In a study conducted by Azhar (2014), there was no difference in sensitivity and specificity of the Tubex test with the Widal test to the clinical symptoms of typhoid fever.

In this study, we aimed to investigate whether there were differences in Widal and Tubex TF serological examinations in febrile patients over three days non-typhoid so that patients could immediately find out whether they had typhoid fever or not.

\section{MATERIALS AND METHODS}

This research conducted at Muhammadiyah Kediri Hospital. 24 patients from July through August 2018 have fever observation criteria for more than 3 days. Inclusion criteria of this study: Patients have a fever for more than 3 days and 7 days for the longest, and not consume antibiotics. Researchers explain to the patients about this study and asking for approval by completing the inform consent is provided.

3-5 $\mathrm{ml}$ blood serum collected from the patients to used in serology analysis (Widal dan Tubex TF). Examination of 24 samples studied by using Widal BIOLABO and TUBEX® TF IDL Biotech. As many as 24 samples examined by Widal with antisera $\mathrm{O}, \mathrm{H}, \mathrm{AH}$, and $\mathrm{BH}$. Agglutination shows a reaction between antisera and antibody 
sufferers. An antibody titer examination from the sample was examined to find out whether positive samples of typhoid fever. The increasing of titer up to 4 times in the sample showed a positive result of typhoid fever. This serological test uses $20 \mu \mathrm{l}$ sample and $20 \mu \mathrm{l}$ antisera for qualitative examination. After the agglutination reaction was known, the sample was followed by semi-quantitative examination to find out antibody titers. Titer is the highest dilution which still shows agglutination reaction.

Twenty-four samples were examined by TUBEX® TF. This examination is semiquantitative colorimetric competitive agglutination test of Inhibition Magnetic Binding Immunoassay (IMBI) method. Tubex TF ${ }^{\circledR}$ used is production from IDL Biotech AB, Sweden. Specimen used serum or plasma heparin samples. Serum samples must be stored at $2-8^{\circ} \mathrm{C}$ or frozen $\left(<-18^{\circ} \mathrm{C}\right.$ if not used immediately).

The examination procedure is carried out in accordance with the procedures issued by the factory. TUBEX ${ }^{\circ}$ TF assessment criteria is negative with value of $0-2$, borderline 3 (not yet concluded), 4 positive value is weak; $6-10$ positive value is strong. While the intermediate values $1,3,5,7$ and 9 are not on the color scale but can be extrapolated.

The comparison of diagnostic results from the two methods will be compared by using Mc Nemar test. Calculation results are done by using SPSS 22.0 program. The significance value of the test is $a=0.05$.

\section{RESULTS AND DISCUSSION}

This examination conducted at Muhammadiyah Hospital in Kediri. The number of samples was 24 samples and examined for 7 days. Parameters tested were Widal and TUBEX® TF. The results of Widal are in Figure 1.

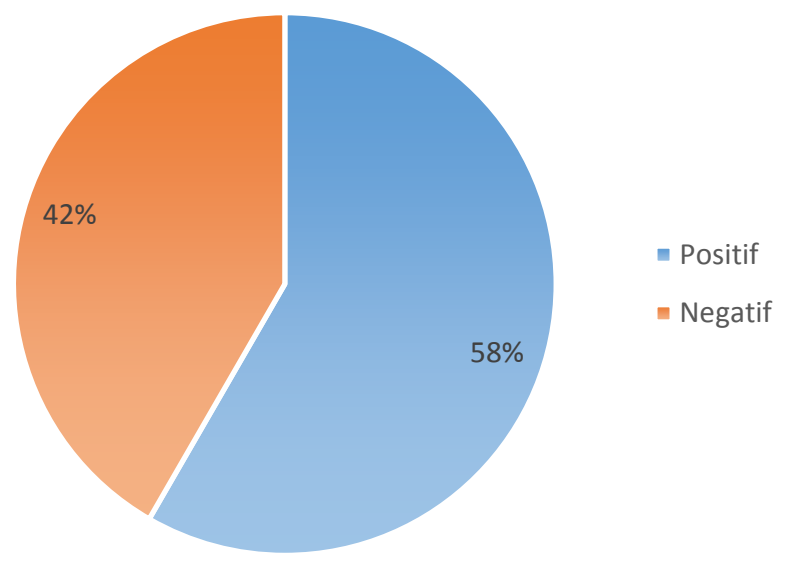

Figure 1. Widal Result Examination

The figure showed from 24 samples, most of them were positive results, namely 14 samples (58\%) and 10 negative results (42\%). Results examination of samples with TUBEX® TF shown in Figure 2. 


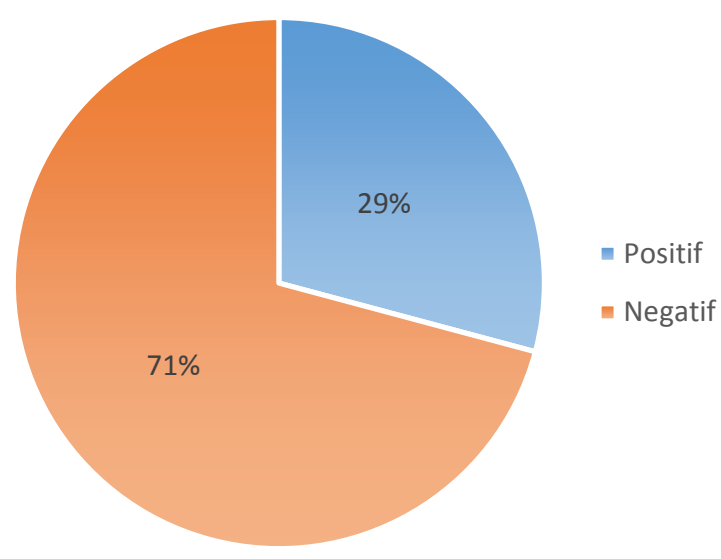

Figure 2. Tubex Results Examination

Figure 2 showed from 24 samples of Tubex Tf results from examination; most of them were negative as many as 17 samples (71\%) and 7 positive samples (29\%). Comparison results of Widal and Tubex TF examinations shown in Table 1.

Table 1. The comparison of Widal and Tubex TF examinations.

\begin{tabular}{ccc}
\hline Tubex Tf & \multicolumn{3}{c}{ Widal } \\
\cline { 2 - 3 } & Positive & Negative \\
\hline Positive & 7 & 0 \\
Negative & 7 & 10 \\
\hline
\end{tabular}

The hypothesis of this study is there is or no difference between Widal and Tubex Tf examinations. The results of Mc Nemar test obtained $p=0.016<\alpha(0,05)$, so it can conclude that there were differences in the results between Widal slide with IgM Anti Salmonella (Tubex Tf) in patients with febrile observation over 3 days at Muhammadiyah Hospital in Kediri.

Febrile can be defined as a condition when individuals run into or have the rising of body temperature more than $37,8^{\circ} \mathrm{C}$ peroral or $37,9^{\circ} \mathrm{C}$ per rectal continuously due to external factors. There is a various pattern of febrile, one of which is a continuous fever pattern. One of the diseases included in a continuous pattern is typhoid fever (Soedarmo, Poorwo, \& Garna, 2010). Typhoid fever is a disease caused by the Gramnegative of Salmonella typhi bacterium (Adijaya, 2016).

Salmonella infection can be categorized into two major types, which caused by the low virulence serotype of Salmonella enteric which causes food poisoning, and which is caused by a high virulence serotype of Salmonella enteric Typhi (S. Typhi), which causes typhus, and serovar group, which known as S. Paratyphi A, B, and C, which causes Paratyphoid. Human is the only host of S. Typhi (Dewan, Corner, Hashizume, \& Ongee, 2013). Lateness and inaccuracies in examination cause not 
immediate treatment of this disease.

The examination methods which are often used to diagnose typhoid fever by hospital and Puskesmas are Widal and Tubex Tf. Widal test is a laboratory examination to detect the presence or absence of patients' antibodies against Salmonella typhi antigens, namely antibodies toward $\mathrm{O}$ antigen (germs' body), $\mathrm{H}$ antigen (flagellum germs), and $\mathrm{Vi}$ antigens (germ capsule). From the three antibodies, only $\mathrm{H}$ and $\mathrm{O}$ antigens antibodies have diagnostic value for typhoid fever (Velina \& Hanif, 2014). Widal test measures agglutination antibodies against $\mathrm{O}$ and $\mathrm{H}$ antigens from $\mathrm{S}$. Typhi in the serum of people suspected of having typhoid fever. Agglutination reactions and the increasing of titer up to 4 times showed positive results and this examination (Ajibola, Mshelia, Gulumbe, \& Eze, 2018), while TUBEX® TF is a rapid test in vitro with Inhibition Magnetic Binding Immunoassay (IMBI) method that can detect specific IgM toward 09 Salmonella enteric Serovar Typhi antigen found in serum of sufferers (llham, Nugraha, \& Purwanta, 2017). The color is proportional to the specific antibody concentration inspected in patient's serum. The results calculated with a visual interpretation of the standard colors found on the Tubex TF kit. Score 0-10 on the color scale (zero according to the absence of specific antibody infections in patient's serum) (Khanna, Khanna, \& Gill, 2015).

Data analysis used was Mc Nemar test. Mc Nemar test is a 2x2 cross test from paired data, McNemar test can see as a type of chi-square test that uses dependent data (e.g., correlated or paired) rather than independent (unbound) samples. McNemar test is a nonparametic statistical test; can be used with data collection that is not normally distributed (Sack, 1995). In McNemar test, data scale used is nominal data scale and dichotomous data, i.e., data with only two codes filled in, such as "Yes" or "No," "Positive" or "Negative" (Santoso, 2014).

The results of this research were $p=0,016<\alpha(0,05)$, mean that there were differences in the results between Widal slide and Tubex Tf methods. Examination of typhoid fever using Tubex Tf method had higher sensitivity and specificity than the Widal slide method. Research conducted by Intan (2010) Widal examination with cut off value $1 / 60$ found sensitivity as many as $36.4 \%$, specificity $87.8 \%$, and accuracy $76.9 \%$ ( $p>0,05)$. On Tubex Tf examination, sensitivity was $92 \%$, specificity was $53.7 \%$, and accuracy was $63.5 \%(p<0,05)$. Tubex $\mathrm{Tf}$ examination has better validity than the Widal examination. Tubex Tf used colored particles to increase sensitivity and specificity by using specific antigens which are only found in Salmonella and only detected IgM and did not detect IgG (Marleni, Iriani, Tjuandra, \& Theodorus, 2014).

Table 1 showed that the differences in the results of Widal slide with Tubex $\mathrm{Tf}$ examination. The difference with the research that has been done by Azhar (2014) explains there is no difference between Widal test and Tubex TF. This test can cause by the presence of cross-reaction with other bacteria, for instance, patients who had other enteric fever, so when the sample tested Widal caused a high titer. Widal test used antigens which were not specific toward Salmonella typhi. This reaction was called anamnestic response and can cause a high false positive value, while Tubex Tf antigen used was Salmonella typhi anti-09, which can distinguish this organism from $>99 \%$ other serotypes of Salmonella bacteria. So it could be that the results of Widal slide examination were false positive, but if the results of the widal slide tests increased the titer for 4 times, so it was positive typhoid fever (Olopoenia, 2000) 
Widal examination measured the level of antibodies that agglutinate antigen $\mathrm{O}$, and $\mathrm{H}$. Antibodies toward $\mathrm{O}$ antigens usually appear on days 6 to 8 and last for 6 months. Antibodies toward $\mathrm{H}$ antigen appear on days 10-12 after onset disease and last 12 months, so patients who previously had typhoid fever showed high titers. In the Tubex test, antibodies examined were $\operatorname{lgM}$. IgM begins formed on the 3rd day, and the titers increased until they reached the peak on day 14, last up to 3 months, then the levels dropped to disappear (Roitt, 2017).

Positive results of Widal examination can cause due to various kinds of things, including patients who had an indication of acute typhoid fever infection or have been infected with typhoid fever before, previous immunization with Salmonella antigens, cross-reactions with non-typhoid Salmonella, reduced variability and standard commercial antigen, malaria infection or Enterobacteriaceae, and another disease such as dengue fever. Negative results of Widal can be caused by Salmonella typhi bacteria, careers, inadequate bacterial antigens on host cells to induce formation of antibodies, difficult technique or mistakes during an examination, and previously received antibiotic therapy (Olopoenia, 2002).

The limitation of Tubex Tf test, which used a colorimetric reaction, had the potential to experience difficulties in interpreting the results in lysis serum. False positive results on Tubex Tf can be caused by infection with non-typhoid Salmonella bacteria; such as Salmonella enteric serotype Enteritidis infection, other bacterial species, and in other conditions such as malaria, immunological disorders, chronic liver disease. And the results of inappropriate antibiotic treatment, healthy people who received typhoid vaccination before, in typhoid fever patients in the last 2 months, while Tubex Tf results were negative for malnutrition, users of immunosuppressant drugs (Olsen et al., 2004).

\section{CONCLUSION}

This study showed differences in the results of Widal slide and IgM Anti Salmonella (Tubex Tf) examination in patients with febrile observation over 3 days. So it can be concluded that Tubex Tf examination is better that Widal slide examination because Tubex $\mathrm{Tf}$ examination uses Salmonella typhi anti-O9 antigen which can distinguish this organism from $>99 \%$ other Salmonella bacteria serotypes so that Tubex Tf examination is more specific.

\section{ACKNOWLEDGMENT}

The author thanks Muhammadiyah Kediri Hospital for facilitating this research and thanks to the patients who were willing to contribute to this research. The suggestion for further research is the possibility to add bacterial culture as the gold standard for sample control to knowing the truth in diagnosis.

\section{REFERENCE}

Abutiheen, A. (2016). Prevalence of Positive Widal test among Healthy Original paper Prevalence of Positive Widal Test among Healthy Personnel in Kerbala. Karbala J. Med, 8(2), 2265-2271.

Adijaya. (2016). the Usage Comparison of Ceftriaxone and Chloramphenicol for Typhoid Fever Treatment: an Evidence Based Case Report. Tropical and Infectious Disease, 74(3), 74-77. 
Azhar, M. A. (2014). Perbandingan Uji Tubex Dengan Widal Terhadap Gejala Klinis Pada Pasien Demam Tifoid Dewasa Di Rumah Sakit Umum Daerah Dr. Zainoel Abidin (RSUDZA) Banda Aceh. Universitas Syiah Kuala.

Dewan, A. M., Corner, R., Hashizume, M., \& Ongee, E. T. (2013). Typhoid Fever and Its Association with Environmental Factors in the Dhaka Metropolitan Area of Bangladesh: A Spatial and Time-Series Approach. PLoS Neglected Tropical Diseases, 7(1), 12-15. https://doi.org/10.1371/journal.pntd.0001998

Ilham, I., Nugraha, J., \& Purwanta, M. (2017). Deteksi IgM Anti Salmonella Enterica Serovar Typhi dengan Pemeriksaan Tubex TF dan Typhidot-M. Jurnal Biosains Pascasarjana, 19(2). https://doi.org/10.20473/BSN.V19I2.5703

Khanna, A., Khanna, M., \& Gill, K. S. (2015). Comparative evaluation of tubex TF(Inhibition magnetic binding immunoassay) for typhoid fever in endemic area. Journal of Clinical and Diagnostic Research, 9(11), DC14-DC17. https://doi.org/10.7860/JCDR/2015/15459.6810

Marleni, M., Iriani, Y., Tjuandra, W., \& Theodorus. (2014). Ketepatan Uji Tubex TF $®$ dalam Mendiagnosis Demam Tifoid Anak pada Demam Hari ke-4. Jurrnal Kedokteran Dan Kesehatan, 1(1), 7-11.

Ogoina, D. (2011). Fever, fever patterns and diseases called "fever" - A review. Journal of Infection and Public Health, 4(3), 108-124. https://doi.org/10.1016/j.jiph.2011.05.002

Olopoenia, L. A. (2002). Classic methods revisited: Widal agglutination test - 100 years later: still plagued by controversy. Postgraduate Medical Journal, 76(892), 80-84. https://doi.org/10.1136/pmj.76.892.80

Olopoenia, L. A., \& King, A. L. (2000). Widal agglutination test - 100 years later: Still plagued by controversy. Postgraduate Medical Journal. https://doi.org/10.1136/pmj.76.892.80

Olsen, S. J., Pruckler, J., Bibb, W., Thi, N., Thanh, M., Trinh, T. M. (Azhar, 2014)Mintz, E. D. (2004). Screening_of_Typhoid_fever.pdf, 42(5), 1885-1889. https://doi.org/10.1128/JCM.42.5.1885

Plaza, J. J. G., Hulak, N., Zhumadilov, Z., \& Akilzhanova, A. (2016). Fever as an important resource for infectious diseases research. Intractable and Rare Diseases Research, 5(2), 97-102. https://doi.org/10.5582/irdr.2016.01009

Ramani, E., Park, J. Y., Wierzba, T. F., Mogasale, V. V., \& Mogasale, V. (2018). Estimating Typhoid Fever Risk Associated with Lack of Access to Safe Water: A Systematic Literature Review. Journal of Environmental and Public Health, 2018, 1-14. https://doi.org/10.1155/2018/9589208

Roitt, I. M. (2017). Roitt's Essential Immunology (13th ed.). United Kingdom: Wiley.

Solimani, G., Shafigji Shahri, E., Salari, Z., Shahrakipoor, M., \& Teimouri, A. (2015). Fever of Unknown Origin in Children Aged Three Months to Fifteen Years. International Journal of Infection, 2(1), 5-7. https://doi.org/10.17795/iji-22906

Velina, V. R., \& Hanif, A. M. (2014). Artikel Penelitian Gambaran Hasil Uji Widal Berdasarkan Lama Demam pada Pasien Suspek Demam Tifoid. Jurnal Fakultas Kedokteran Universitas Andalas, 5(3), 687-691.

Walter, E. J., Hanna-Jumma, S., Carraretto, M., \& Forni, L. (2016). The pathophysiological basis and consequences of fever. Critical Care, 20(1), 1-10. https://doi.org/10.1186/s13054-016-1375-5 
Wardiyah, A., Setiawati, \& Romayati, U. (2016). Perbandingan Efektivitas Pemberian Kompres Hangat dan Tepid Spoge terhadap Penurunan Suhu Tubuh Anak yang Mengalami Demam di ruang Alamanda RSUD dr.H Abdul Moeloek. Kesehatan Holistik, 10(1), 36-44. Retrieved from http://malahayati.ac.id/wpcontent/uploads/2016/07/Jurnal-Aryanti-Setiawati-Umi-Romayati.pdf

Wasihun, A. G., Muthupandian, S., Dejene, T. A., Haile, T. D., Gebremariam, S. A., Wlekidan, L. N., \& Welderufael, A. L. (2015). Diagnosis and Treatment of Typhoid Fever and Associated Prevailing Drug Resistance in Northern Ethiopia. International Journal of Infectious Diseases, 35, 96-102. https://doi.org/10.1016/j.ijid.2015.04.014

Zhou, L., Darton, T. C., Waddington, C. S., Blohmke, C. J., Pollard, A. J., Jones, C., \& Baker, S. (2017). Blood culture-PCR to optimise typhoid fever diagnosis after controlled human infection identifies frequent asymptomatic cases and evidence of primary bacteraemia. Journal of Infection, 74(4), 358-366. https://doi.org/10.1016/j.jinf.2017.01.006 